
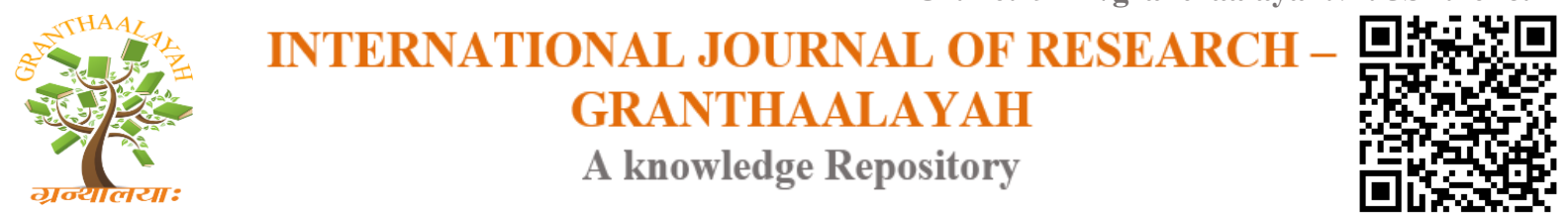

Management

\title{
PROBLEMS FACED BY WOMEN ENTREPRENEURS
}

\author{
P.M.SirumalarRajam ${ }^{1}$, Dr. K. V. Soundararaja ${ }^{2}$ \\ ${ }^{1}$ Ph.D Research Scholar, Department of Commerce, S.T.Hindu College, INDIA \\ ${ }^{2}$ Associate Professor, Department of Commerce, S.T.Hindu College, INDIA
}

\begin{abstract}
Women constitute around half of the total world population. So is in India also. They are, therefore, regarded as the better half of the society. In traditional societies, they were confined to the four walls of houses performing household activities. In modern societies they have come out of the four walls to participate in all sorts of activities. The global evidence buttress that women have been performing exceedingly well in different spheres of activities like academics, politics, administration, social work and so on. Now, have started plunging into industry also and running their enterprises successfully. Therefore, white discussing on entrepreneurial development, if seems in the fitness on the context to study about the development of women entrepreneurs in the country.
\end{abstract}

Keywords:

Women Entrepreneurs, problems, attitude of women entrepreneurs.

Cite This Article: P.M.SirumalarRajam, and Dr. K. V. Soundararaja, "PROBLEMS FACED BY WOMEN ENTREPRENEURS" International Journal of Research - Granthaalayah, Vol. 4, No. 5: SE (2016): 77-86.

\section{INTRODUCTION}

Women constitute around half of the total world population. So is in India also. They are, therefore, regarded as the better half of the society. In traditional societies, they were confined to the four walls of houses performing household activities. In modern societies they have come out of the four walls to participate in all sorts of activities. The global evidence buttress that women have been performing exceedingly well in different spheres of activities like academics, politics, administration, social work and so on. Now, have started plunging into industry also and running their enterprises successfully. Therefore, white discussing on entrepreneurial development, if seems in the fitness on the context to study about the development of women entrepreneurs in the country.

All business owners face certain challenges, but women, because of the genders, often have additional challenges and obstacles than their male peers. Working women who have children experience even more demands on time, energy and resources. But this does not mean women 
are less successful than men in fact, statistics show that women are starting business at more than twice the rate of male-majority-owned business. The growing success rate of women entrepreneurs shows that they are resourceful, and able to succeed, despite the odds.

\section{STATEMENT OF THE PROBLEM}

In olden days, women were married at an early age and their focus was centered on the family. They were uneducated and ignorant of the conditions prevailing in the country. The post independent period witnessed a significant improvement in women's education in India. In Tamil Nadu, literacy level among the female population has gone up over the decades, a little faster than the males. As more and more women were educated, they turned up to seek employment. In course of time, they compete with men folk in education and training and staked their claim for equal jobs.

Due to acute shortage of job opportunities and stiff competition prevailing, more and more women have opted for entrepreneurship and set up their own ventures. Moreover emergence of nucleus family, non-availability of reliable servants and lack of proper hygienic crèches force many a woman to leave their jobs and start their own business.

As the number of women entrepreneurs are increasing every year, the Govt. is also keen in giving a helping hand to these entrepreneurs. A preferential allotment of sheds for women in Industrial estates, concessional rates of loan, interest, subsidy for women who set up small-scale industrial units, capital subsidy in backward areas, marketing services, streamlining the availability of term loan and working capital and the like are the main assistances offered by the Govt.

The present study focuses mainly on the problems faced by the women entrepreneurs (SHGs) in Kanyakumari District, and what are the factors that can solve the problems of the women entrepreneurs (SHGs). The researcher proceeds to sort out it through her findings.

\section{OBJECTIVES OF THE STUDY}

- To analyze the problems faced by the women entrepreneurs in Kanyakumari district.

- To find out the ways to overcome the same.

\section{RESEARCH METHODOLOGY}

The very objective of the research is to find clues to the problems faced by women entrepreneurs in the study area necessitated the use of primary as well as a secondary data. A sample size of 600 women entrepreneurs (SHGs) was chosen for gathering primary data by adopting multi stage random sampling method. The primary data collection was undertaken with the help of Interview

schedule. The secondary data were collected from books, reports, journals, magazines and websites. 


\section{SAMPLING SIZE}

Table 1.4 shows that there are 16153 SHGs comprising 9 blocks in Kanyakumari District of TamilNadu. In 9 blocks, there are 1758 SHGs doing business in Kanyakumari District. The researcher has selected 5 blocks of top business done by SHGs. Totally, there are 1147 groups in 5 blocks. In each block, the researcher selected 10 percent samples (114.7) that mean 115 groups. In each group, the researcher selected 6 samples and totally 690 samples were selected. 90 Samples were incomplete and hence rejected the remaining 600 were selected. Among the 600 samples, 200 are manufacturing another 200 are trading and the remaining 200 are services.

Table 1: SAMPLE SIZE OF WOMEN ENTREPRENEURES (SHG) IN KANYAKUMARI DISTRICT (BLOCKWISE)

\begin{tabular}{|l|l|l|l|l|l|}
\hline & TNWE & Mfg & Trading & Services & T \\
Kanyakumari district & In & S & S & S & N \\
& KK & S & S & S & W \\
& 275 & 30 & 45 & 40 & 115 \\
\hline Agasteeswaram & 232 & 20 & 20 & 20 & 60 \\
\hline Thovalai & 212 & 25 & 30 & 30 & 85 \\
\hline Rajakkamangalam & 215 & 25 & 20 & 20 & 65 \\
\hline Kurunthencode & 210 & 20 & 20 & 10 & 50 \\
\hline Thuckalay & 120 & 15 & 10 & 15 & 40 \\
\hline Killiyoor & 121 & 15 & 15 & 15 & 45 \\
\hline Thiruvattar & 213 & 25 & 25 & 30 & 80 \\
\hline Melpuram & 160 & 25 & 15 & 20 & 60 \\
\hline Munchirai & $\mathbf{1 7 5 8}$ & $\mathbf{2 0 0}$ & $\mathbf{2 0 0}$ & $\mathbf{2 0 0}$ & $\mathbf{6 0 0}$ \\
\hline TOTAL & & R & & \\
\hline
\end{tabular}

Source: Tamil Nadu Corporation for Development of Women Ltd.

[TNWE in KK - Total Number of Women Entrepreneurs in Kanyakumari district, SSR- Sample Size of Respondents, TNWE - Total Number of Women Entrepreneurs]

\section{ANALYSIS AND INTERPRETATION}

Above table shows that out of 600 sample respondents, 69.3 percent of the respondents belong to the age group of 30-40 years. Among the total respondents 14.7 percent respondents completed their HSC. Illiteracy level of respondents is 17.3 percent. It is found that out of 600sample respondents, 89.3 percent respondents were married. It clearly reveals that married women were highly engaged in business activities than other. It is found that nearly 49.3 percent of the respondents have their family monthly income exceed over Rs.20000-30000. It reveals that 45.3 percent of the 600 sample respondents' family monthly income is below Rs.20000. As per the collected data with 600 sample respondents it reveals that 57.3 percent members are earning numbers in a family. It shows that 2 or 3 members belong to the family are earning for their family. The data worked with sample respondents shows an output 71.64 percent of the respondents initial capital investments is ranging from 50,000 to 1,00,000.

\section{Source: Primary data}


Table 2: ATTITUDES OF THE WOMEN ENTREPRENEURES TOWARDS PERSONAL PROBLEM

\begin{tabular}{|c|c|c|c|c|c|}
\hline \multirow[t]{2}{*}{ SI.NO } & \multirow[t]{2}{*}{ Particulars } & \multicolumn{3}{|c|}{ Mean Score of Respondents } & \multirow[b]{2}{*}{ F-Statistic } \\
\hline & & Manufacturing & Trading & Service & \\
\hline 1 & $\begin{array}{l}\text { Poor risk taking } \\
\text { ability }\end{array}$ & 4.2550 & 4.5750 & 4.5550 & 9.262 \\
\hline 2 & $\begin{array}{l}\text { Lack of proper } \\
\text { training }\end{array}$ & 3.8650 & 3.6050 & 3.2200 & 15.159 \\
\hline 3 & $\begin{array}{l}\text { Inadequate } \\
\text { predicting } \\
\text { efforts }\end{array}$ & 4.7600 & 4.0850 & 3.1650 & 173.320 \\
\hline 4 & $\begin{array}{l}\text { Excessive } \\
\text { tensions and } \\
\text { challenges }\end{array}$ & 4.3450 & 4.5950 & 4.4600 & 4.906 \\
\hline 5 & $\begin{array}{l}\text { Lack of } \\
\text { communication } \\
\text { skills }\end{array}$ & 4.4500 & 4.5550 & 4.6000 & 2.205 \\
\hline 6 & $\begin{array}{l}\text { Lack of self } \\
\text { confidence }\end{array}$ & 3.6600 & 3.6600 & 3.2400 & 7.886 \\
\hline 7 & $\begin{array}{ll}\text { Heavy } & \text { work } \\
\text { schedule } & \end{array}$ & 2.8800 & 3.6400 & 2.5600 & 31.772 \\
\hline 8 & $\begin{array}{l}\text { Lack of rest and } \\
\text { sleep }\end{array}$ & 3.6800 & 3.6800 & 2.4250 & 94.419 \\
\hline 9 & $\begin{array}{l}\text { Lack of } \\
\text { managerial skill }\end{array}$ & 4.4700 & 4.3350 & 4.600 & 5.570 \\
\hline 10 & $\begin{array}{ll}\text { Lack } & \text { of } \\
\text { awareness } & \\
\end{array}$ & 4.3250 & 4.4450 & 3.2700 & 105.588 \\
\hline
\end{tabular}

Source: primary data

The highly perceived variables among manufacturing business sector on the suggestion to solve the problems faced by the women entrepreneurs are poor risk taking ability, inadequate predicting efforts, excessive tensions and challenges, lack of communication skill, Lack of managerial skill and lack of awareness they perceived since mean scores are 4.2550, 4.7600, $4.3450,4.4500,4.4700,4.3250$ respectively.

In case of Trading sector of women entrepreneurs' the highly perceived variables are poor risk taking ability, inadequate predicting efforts, Excessive tension and challenges, lack of communication skill, lack of managerial skill, lack of awareness since their mean scores are $4.5750,4.0850,4.5950,4.5550,4.3350,4.4450$ respectively.

The highly perceived variables among Services sector of women entrepreneurs are poor risk taking ability, Excessive tensions and challenges, lack of communication skill, and lack of managerial skill since their mean scores are 4.5550,4.4600,4.6000 and4.6000 respectively. 
The significant difference among the three types of business is identified regarding 5 variables since the respective $\mathrm{F}$ statistics are significant at five percent level. The above said 10 variables related to the suggestion to overcome the personal problem of women entrepreneurs are taken for narration analysis with the help of factor analysis.

\section{MARKETING PROBLEM}

The following table explains the attitude of the women entrepreneurs towards marketing problem on F-Statistics.

\section{Table 3: ATTITUDE OF THE WOMEN ENTREPRENEURES TOWARDS MARKETING PROBLEM}

\begin{tabular}{|l|l|l|l|l|l|}
\hline \multirow{2}{*}{$\begin{array}{l}\text { SI. } \\
\text { NO }\end{array}$} & \multirow{2}{*}{ Particulars } & \multicolumn{3}{|l|}{ Mean Score of Respondents } & \\
\cline { 3 - 6 } & \multicolumn{2}{|l|}{ Manufacturing } & Trading & Service & F-Statistic \\
\hline 1 & $\begin{array}{l}\text { Lack of storage } \\
\text { facilities }\end{array}$ & 4.4150 & 4.2800 & 2.5650 & 227.588 \\
\hline 2 & $\begin{array}{l}\text { Lack of idea in } \\
\text { Marketing }\end{array}$ & 4.1750 & 4.3600 & 3.2400 & 53.974 \\
\hline 3 & $\begin{array}{l}\text { Lack of } \\
\text { marketing } \\
\text { facilities }\end{array}$ & 4.6800 & 4.5750 & 4.6000 & 2.558 \\
\hline 4 & $\begin{array}{l}\text { Lack } \\
\text { marketing skills }\end{array}$ & 4.5200 & 4.3300 & 3.2000 & 131.000 \\
\hline 5 & $\begin{array}{l}\text { Inadequate } \\
\text { market centre }\end{array}$ & 4.4500 & 4.2400 & 3.0350 & 122.839 \\
\hline 6 & $\begin{array}{l}\text { Inadequate } \\
\text { market training }\end{array}$ & 4.2100 & 4.0150 & 3.0800 & 77.952 \\
\hline 7 & $\begin{array}{l}\text { Higher rate credit } \\
\text { transaction }\end{array}$ & 4.5700 & 4.5900 & 4.6000 & 0.125 \\
\hline 8 & $\begin{array}{l}\text { Lack } \\
\text { information about } \\
\text { market available }\end{array}$ & 4.3450 & 4.5850 & 4.4600 & 4.373 \\
\hline
\end{tabular}

Source: Primary data

The highly perceived variables among Manufacturing business sector on the suggestion to solve the problems faced by the women entrepreneurs are Lack of storage facilities, Lack of idea in marketing, Lack of marketing facilities, Lack of marketing skills, Inadequate market centre, Inadequate market training, Higher rate credit transaction, Lack of information about market available they perceived since mean scores are 4.4150, 4.1750, 4.6800, 4.5200, 4.4500, 4.2100, 4.5700 and 4.3450 respectively. 
In case of trading sector of women entrepreneurs the highly perceived variables are Lack of storage facilities, Lack of idea in marketing, Lack of marketing facilities, Lack of marketing skills, Inadequate market centre, Inadequate market training, Higher rate of credit transaction, Lack of information about market available and they perceived since their mean scores are $4.2800,4.3600,4.5750,4.3300,4.2400,4.0150,4.5900$ and 4.5850 respectively.

The highly perceived variables among services sector of women entrepreneurs are Lack of marketing facilities, higher rate credit transaction, Lack of information about market available since their mean scores are 4.6000, 4.6000 and 4.4600 respectively.

The significant difference among the three types of business is identified regarding 5 variables since the respective $\mathrm{F}$ statistics are significant at five percent level. The above said 8 variables related to the suggestion to overcome the personal problem of women entrepreneurs are taken for narration analysis with the help of factor analysis.

\section{FINANCE PROBLEM}

The following table shows the attitude of the women entrepreneurs towards finance problem in three categories, analyzed in F- Statistics.

Table 4: ATTITUDE OF THE WOMEN ENTREPRENEURES TOWARDS FINANCE PROBLEM

\begin{tabular}{|c|c|c|c|c|c|}
\hline \multirow{2}{*}{$\begin{array}{l}\text { SI. } \\
\text { NO }\end{array}$} & \multirow{2}{*}{ Particulars } & \multicolumn{3}{|c|}{ Mean Score of Respondents } & \multirow{2}{*}{$\begin{array}{l}\text { F- } \\
\text { Statistic }\end{array}$} \\
\hline & & Manufacturing & Trading & Service & \\
\hline 1 & High rate of interest & 4.6100 & 4.3600 & 3.1200 & 143.227 \\
\hline 2 & $\begin{array}{l}\text { High credit seeking behavior of } \\
\text { the customer }\end{array}$ & 4.4700 & 4.3700 & 4.6000 & 4.334 \\
\hline 3 & $\begin{array}{l}\text { High dependence of family and } \\
\text { relatives }\end{array}$ & 4.4500 & 4.2800 & 4.0400 & 10.184 \\
\hline 4 & $\begin{array}{l}\text { Inability to provide securities } \\
\text { for loans }\end{array}$ & 4.2750 & 3.8800 & 2.7650 & 88.115 \\
\hline 5 & Shortage of own funds & 4.4700 & 4.3400 & 4.6000 & 5.533 \\
\hline 6 & $\begin{array}{l}\text { Lack of support from financial } \\
\text { institutions }\end{array}$ & 4.1550 & 4.4000 & 4.2000 & 3.919 \\
\hline 7 & Delay in sanctioning loan & 4.5400 & 4.2550 & 4.1450 & 8.885 \\
\hline 8 & Inadequate credit facility & 4.3450 & 4.5800 & 4.4600 & 4.232 \\
\hline
\end{tabular}

Source: Primary source

The highly perceived variables among manufacturing business sector on the suggestion to solve the problems faced by the women entrepreneurs are: 
High rate of interest, High credit seeking behavior of the customer, High dependence of family and relatives, Inability to provide securities for loans, Shortage of own funds, Lack of support from financial institutions, Delay in sanctioning loan, Inadequate credit facility they perceived since mean scores are 4.6100, 4.4700, 4.4500, 4.2750, 4.4700, 4.1550, 4.5400 and 4.3450 respectively.

In case of trading sector women entrepreneurs' the highly perceived variables are High rate of interest, High credit seeking behavior of the customer, High dependence of family and relatives, Shortage of own funds, Lack of support from financial institutions, Delay in sanctioning loan, Inadequate credit facility they perceived since mean scores are 4.3600, 4.3700, 4.2800, 4.3400, $4.4000,4.2550$ and 4.5800 respectively.

The highly perceived variables among Services sector women entrepreneurs are High credit seeking behavior of the customer, High dependence of family and relatives, Shortage of own funds, Lack of support from financial institutions, Delay in sanctioning loan, Inadequate credit facility they perceived since mean scores are 4.6000, 4.0400, 4.6000, 4.2000, 4.1450 and 4.4600 respectively.

The significant difference among the three types of businesses is identified regarding 5 variables since the respective $\mathrm{F}$ statistics are significant at five percent level. The above said 8 variables related to the suggestion to overcome the personal problem of women entrepreneurs are taken for narration analysis with the help of factor analysis.

\section{MATERIAL PROBLEM}

The following table reveals that attitude of the women entrepreneurs towards raw material problem in F- Statistics.

Table 5: ATTITUDE OF THE WOMEN ENTREPRENEURES TOWARDS RAW MATERIAL PROBLEM

\begin{tabular}{|l|l|l|l|l|l|}
\hline \multirow{2}{*}{$\begin{array}{l}\text { SI. } \\
\text { NO }\end{array}$} & \multirow{2}{*}{ Particulars } & \multicolumn{3}{|c|}{ Mean Score of Respondents } & \multirow{2}{*}{ F-Statistic } \\
\cline { 3 - 5 } & & Manufacturing & Trading & Service & \\
\hline 1 & Scarcity & 4.3600 & 4.4800 & 4.0800 & 10.169 \\
\hline 2 & High price & 3.8100 & 3.0250 & 3.0250 & 40.303 \\
\hline 3 & Low quality & 4.4700 & 4.2750 & 4.6000 & 8.199 \\
\hline 4 & High transport cost & 4.3450 & 4.4700 & 4.4600 & 1.344 \\
\hline 5 & Other difficulties & 4.0500 & 3.3250 & 3.9200 & 22.243 \\
\hline
\end{tabular}

Source: Primary source

The highly perceived variables among manufacturing business sector on the suggestion to solve the problems faced by the women entrepreneurs are Scarcity, Low quality, High transport cost, and other difficulties they perceived since mean scores are 4.3600, 4.4700, 4.3450 and 4.0500 respectively. 
In case of trading sector of women entrepreneurs' the highly perceived variables are Scarcity, Low quality and High transport cost they perceived since mean scores are 4.4800, 4.2750 and 4.4700 respectively.

The highly perceived variables among Services sector women entrepreneurs are Scarcity, Low quality and High transport cost they perceived since mean scores are 4.0800, 4.6000 and 4.4600 respectively.

The significant difference among the three types of businesses is identified regarding 2 variables since the respective $\mathrm{F}$ statistics are significant at five percent level. The above said 5 variables related to the suggestion to overcome the personal problem of women entrepreneurs are taken for narration analysis with the help of factor analysis.

\section{POWER PROBLEM}

The following table explains the attitude of the women entrepreneurs towards power problem in F-Statistics.

\section{Table 6: ATTITUDE OF THE WOMEN ENTREPRENEURES TOWARDS POWER PROBLEM}

\begin{tabular}{|l|l|l|l|l|l|}
\hline \multirow{2}{*}{$\begin{array}{l}\text { SI. } \\
\text { NO }\end{array}$} & \multirow{2}{*}{ Particulars } & \multicolumn{3}{|l|}{ Mean Score of Respondents } & \multirow{2}{*}{ F-Statistic } \\
\cline { 3 - 5 } & & Manufacturing & Trading & Service & \\
\hline 1 & High cost & 4.6000 & 3.9200 & 4.0800 & 31.611 \\
\hline 2 & Power failure & 4.3300 & 4.2900 & 4.6000 & 7.052 \\
\hline 3 & Low voltage & 4.1950 & 3.8050 & 3.9050 & 5.568 \\
\hline
\end{tabular}

Source: Primary data.

The highly perceived variables among Manufacturing business sector on the suggestion to solve the problems faced by the women entrepreneurs are High cost, Power failure and Low voltage since mean scores are 4.6000, 4.3300 and 4.1950 respectively. In case of Trading sector women entrepreneurs the highly perceived variables are Power failure they perceived since mean scores are 4.2900 respectively. The highly perceived variables among Services sector of women entrepreneurs are High cost and Power failure they perceived since mean scores are 4.0800 and 4.6000 respectively. The significant difference among the three types of businesses is identified regarding ' 1 ' variable since the respective $F$ statistics are significant at five percent level. The above said 3 variables related to the suggestion to overcome the personal problem of women entrepreneurs are taken for narration analysis with the help of factor analysis.

To analyse the problem faced by the women entrepreneurs in Kanyakumari district and mainly focuses problems such as personal problem, problem of marketing, problem of finance, raw material problem, labour problem and problem of power. F-Statistics, Index score and constraint index have been calculated. 


\section{SUGGESTIONS}

Finance is the first major problem for women. The banks and other financial institutions should provide loan to the women who are willing to do business without lengthily procedure. Hence the government can provide interest free loans, capital subsidy, power tariff subsidy, tax concessions and marketing assistance to encourage women entrepreneurship.

Most of the women entrepreneurs are of the opinion that because of lack of training they find difficulty in surviving in the market. Hence the government should conduct frequent training programmes with regard to new production techniques, sales techniques etc. This training should be made compulsory for women entrepreneurs.

Marketing their products is one of the main problems for women entrepreneurs. Hence women co-operative societies can be started to procure the products from women entrepreneurs and they can help them in selling their products at reasonable prices.

Most of the women have entered in to entrepreneurship only after their marriage. Unmarried women can be more successful than married women, in entrepreneurship business if they are properly trained. Hence the govt. can conduct entrepreneurial training programmes in colleges at least once in a month. This will motivate more young women to enter into business of their own. National commission for self-employed women recommended that where raw materials are not easily accessible, alternative channels should be identified through which good quality of raw material would be procured at reasonable prices.

The Government can provide electricity charges at low cost without power failure which will make women entrepreneurs to gain more in their business.

\section{CONCLUSION}

It can be concluded that the role of women entrepreneurs in promoting industrial development is also being recognized and steps are being taken to promote women entrepreneurship. Making them realize their strengths and important position in the society and the greatest contribution they can make for the manufacturing, trading and service industries as well as the entire economy. Apart from these Women's participation in economic development calls for arrangements that would lighten their domestic work load and release them for other economic and socially productive work. Though women entrepreneurs face many problems and challenges in their path to become a successful entrepreneur the government has taken many initiatives for the growth of women entrepreneurs. Finally, the researcher has given appropriate suggestions to overcome the problem of women entrepreneurs. If the financial institutions, government and non-government organizations follow the suggestions, it will help to increase the growth of Indian economy.

\section{REFERENCES}

[1] A Study of Challenges and opportunities of women entrepreneurship S. Banu, National Conference on Challenges in Business Practices, (CIBP 2012 March). Unit, K.K.Dist. 
[2] Entrepreneurial Development (Book) S.S. Khanka (1999).

[3] Entrepreneurs (Magazine) - KiranMazumdar Shaw (2011).

[4] Entrepreneurs (Magazine) - RegupathiSinghania (2010).

[5] Golden, S. A. R. (2011). A Study On Investment Pattern And Preference Of Investors In Trichy City, Tamil Nadu. RETELL, 12(1), 20-24.

[6] kalyan-city-blogspot.com-GauravAkrani.

[7] Tamil Nadu Corporation for Development of Women Ltd, Project Implementation

[8] www.carolroth.com

[9] www.preservearticles.com

[10] www.publishyourarticles.net 